\title{
Effects of an exogenous enzyme preparation on microbial protein synthesis, enzyme activity and attachment to feed in the Rumen Simulation Technique (Rusitec)
}

\author{
Y. Wang ${ }^{1}$, T. A. McAllister ${ }^{1}$, L. M. Rode $^{1}$, K. A. Beauchemin ${ }^{1}$, D. P. Morgavi ${ }^{1}$, V. L. Nsereko ${ }^{1} \dagger$, \\ A. D. Iwaasa ${ }^{2}$ and W. Yang ${ }^{1}$ \\ ${ }^{1}$ Agriculture and Agri-Food Canada Research Centre, P. O. Box 3000, Lethbridge, Alberta, Canada T1J 4 B1 \\ ${ }^{2}$ Agriculture and Agri-Food Canada Semiarid Prairie Agricultural Research Centre, P.O. Box 1030, Swift Current, \\ Saskatchewan, Canada S9H $3 X 2$
}

(Received 4 April 2000 - Revised 5 September 2000 - Accepted 20 October 2000)

\begin{abstract}
The effects of an exogenous enzyme preparation, the application method and feed type on ruminal fermentation and microbial protein synthesis were investigated using the rumen simulation technique (Rusitec). Steam-rolled barley grain and chopped alfalfa hay were sprayed with water (control, C), an enzyme preparation with a predominant xylanase activity (EF), or autoclaved enzyme (AEF) $24 \mathrm{~h}$ prior to feeding, or the enzyme was supplied in the buffer infused into the Rusitec (EI). Microbial N incorporation was measured using $\left({ }^{15} \mathrm{NH}_{4}\right)_{2} \mathrm{SO}_{4}$ in the buffer. Spent feed bags were pummelled mechanically in buffer to segregate the feed particleassociated (FPA) and feed particle-bound (FPB) bacterial fractions. Enzymes applied to feed reduced neutral-detergent fibre content, and increased the concentration of reducing sugars in barley grain, but not alfalfa hay. Ruminal cellulolytic bacteria were more numerous with EF than with C. Disappearance of DM from barley grain was higher with EF than with C, but alfalfa was unaffected by EF. Treatment EF increased incorporation of ${ }^{15} \mathrm{~N}$ into FPA and FPB fractions at 24 and $48 \mathrm{~h}$. In contrast, AEF reduced the $24 \mathrm{~h}$ values, relative to C; AEF and C were similar at $48 \mathrm{~h}$. Infused enzyme (EI) did not affect ${ }^{15} \mathrm{~N}$ incorporation. Xylanase activity in effluent was increased by EF and EI, compared to $\mathrm{C}$, but not by AEF. Xylanase activity in FPA was higher at $48 \mathrm{~h}$ than at $24 \mathrm{~h}$ with all treatments; it was higher with EF than $\mathrm{C}$ at 24 and $48 \mathrm{~h}$, but was not altered by AEF or EI. Applying enzymes onto feeds before feeding was more effective than dosing directly into the artificial rumen for increasing ruminal fibrolytic activity.
\end{abstract}

Rusitec: Exogenous enzymes: Ruminal microbes: Digestion: ${ }^{15} \mathrm{~N}$ incorporation

In ruminants, digestion of the structurally complex fibrous compounds in plant cell walls is accomplished through the enzymic action of the ruminal microflora, but it is far from complete. There is considerable room to enhance the utilization of fibrous feeds by ruminant livestock. Interest in using exogenous enzymes to complement or stimulate existing digestive activity in the rumen has increased recently, but production responses have been highly variable. Positive effects (Beauchemin et al. 1995; Lewis et al. 1995; Stokes \& Zhang 1995; Feng et al. 1996; Treacher et al. 1996; McAllister et al. 1999), negative effects (Theurer et al. 1963; Svozil et al. 1989), and lack of effects (Beauchemin et al. 1995; Chen et al. 1995; McAllister et al. 2000) of enzymes on ruminant production have been reported. These inconsistencies have been attributed to differences in crude enzyme preparations, type of diets and/or application methods (Beauchemin et al. 1998; McAllister et al. 2000). It is known that microbial attachment to and colonization of feeds is essential for their degradation in the rumen (McAllister et al. 1994; Flint \& Forsberg, 1995), but the mechanism by which exogenous enzymes alter feed digestion has not been clearly defined. In theory, these enzymes could work synergistically with, complementarily with, antagonistically against, or

\footnotetext{
Abbreviations: AEF, autoclaved exogenous enzyme applied onto each feed type; $\mathrm{C}$, control (no added enzyme); EF, exogenous enzyme applied onto each feed type; EI, exogenous enzyme included in infusion buffer; DMD, disappearance of DM; FPA, feed particle-associated; FPB, feed particlebound; NAN, non-ammonia nitrogen; NDF, neutral-detergent fibre; RS, reducing sugars; VFA, volatile fatty acids.

* Corresponding author: Dr T. A. McAllister, fax +1 (403) 382-3156, email mcallister@em.agr.ca

$\dagger$ Current address: Pioneer Hi-Bred International, Inc., 7300 N.W. 62 Avenue, Box 1004, Johnston, IA, USA 50131-1004.
} 
independently from endogenous microbial populations. In this study, the rumen simulation technique (Rusitec) was used to investigate specific effects of exogenous fibrolytic enzymes on rumen microbial populations and microbial protein synthesis in conjunction with fermentation and digestion of forage (alfalfa) and concentrate (barley grain).

\section{Materials and methods}

\section{Rusitec, inoculum, diets and experimental design}

Inoculum (ruminal fluid and solid digesta) for two eightvessel Rusitec units (Czerkawski \& Breckenridge, 1977) was obtained from three Holstein cows in early lactation, maintained on a 60:40\% concentrate:barley silage diet (as-fed basis). Inoculum was prepared, and fermentations were established in the Rusitec units as described by Wang et al. (1998), except that the slow-speed centrifugation of ruminal fluid was omitted and the buffer infused into the fermenter vessels (McDougall, 1948) was modified to contain $\left(\mathrm{NH}_{4}\right)_{2} \mathrm{SO}_{4} 0 \cdot 3 \mathrm{~g} / \mathrm{l}$. Diet (DM basis) for each of the 16 vessels comprised $5 \mathrm{~g}$ chopped $(0.5 \mathrm{~cm})$ alfalfa hay and $5 \mathrm{~g}$ steam-rolled barley grain, contained in separate feed bags. The four experimental treatments $(n$ 4) were: no exogenous enzyme (control, C), exogenous enzyme delivered in the infused buffer (EI), exogenous enzyme applied onto each feed type (EF) and autoclaved enzyme applied onto each feed type (AEF). Before commencing data collection, a $12 \mathrm{~d}$ adaptation period was allowed during which gas and effluent volumes and fermenter liquid $\mathrm{pH}$ were monitored in order to assess the stability of the fermentation.

The enzyme used in this study was a powdered preparation from Trichoderma longibrachiatum (Biovance Technologies Inc., Omaha, NB, USA) that contained a mixture of hydrolases. The main enzyme activity present was xylanase $(817$ units/g, with one unit defined as release of $1 \mathrm{mmol}$ xylose per min from oat spelt xylan (X-0627, Sigma Chemical Company, St Louis, MO, USA) under incubation conditions of $39^{\circ} \mathrm{C}$ and $\mathrm{pH} 6 \cdot 5$ ). Feeds for $\mathrm{C}$ and EI vessels were sprayed with deionized water $(10 \mathrm{ml} / 100 \mathrm{~g}$ DM) using a hand-held, single-nozzle spray bottle. In the same manner, feeds for EF and AEF were sprayed with $1 \%$ aqueous solutions of enzyme $(10 \mathrm{ml} / 100 \mathrm{~g} \mathrm{DM})$, except that, for AEF, the enzyme solution was autoclaved (20 min, $121^{\circ} \mathrm{C}$ ), cooled to room temperature, and homogenized in a blender before application. After spraying, the DM content of the barley grain and alfalfa hay were 79.1 (SD 0.49) \% and 83.7 (SD 0.81) \%, respectively. The treated feeds were weighed into feed bags ( $5 \mathrm{~g}$ DM each), then stored at room temperature for $24 \mathrm{~h}$ prior to transfer to a $4^{\circ} \mathrm{C}$ cooler. Feeds were treated every $3 \mathrm{~d}$ throughout the experiment. For EI vessels, the infusate was prepared daily by dissolving the enzyme (15 mg/l) in the McDougall (1948) buffer. The EI infusate was stored on ice throughout the experiment. The enzyme concentration was calculated from the infusion rate and DM content of the feeds, so that approximately equal amounts of enzyme were delivered to each vessel daily by the two methods (EI and EF/AEF).

\section{Sample collection and analyses}

Fermentation characteristics and DM disappearance. Effluent and gas produced by each fermentation vessel were measured daily over the $25 \mathrm{~d}$ of the study (Wang et al. 1998). Methane in the gas was determined on days 17 and 18 on subsamples of gas from the collection bags, using a Varian 3400 gas chromatograph equipped with a CTR I column (Alltech Associates, Inc., Deerfield, IL, USA). The injection volume was $100 \mu \mathrm{l}$. Fermenter liquids were subsampled daily from day 16 to day 21 , and analysed for ammonia and volatile fatty acids (VFA) as described by Wang et al. (1998). Disappearances of DM (DMD) from alfalfa hay and barley grain were determined using the $48 \mathrm{~h}$ bags from day 16 to day 21 (6 d) as described by Wang et al. (1998).

Microbial protein synthesis. To estimate microbial protein synthesis, effluent and feed residue solids were sampled on day 14 for determination of background ${ }^{15} \mathrm{~N}$, and the $\left(\mathrm{NH}_{4}\right)_{2} \mathrm{SO}_{4}$ in the McDougall's buffer was replaced with ${ }^{15} \mathrm{~N}$-enriched $\left(\mathrm{NH}_{4}\right)_{2} \mathrm{SO}_{4}$ (Sigma Chemical Co., minimum ${ }^{15} \mathrm{~N}$ enrichment $10 \cdot 01$ atom $\%$ ) for the remainder of the experiment. On days 22 and 25, $24 \mathrm{~h}$ accumulations of preserved effluent from each vessel were sampled for determination of ${ }^{15} \mathrm{~N}$ enrichment in non-ammonia nitrogen (NAN). Effluent was preserved by placing $18 \mathrm{ml}$ of $25 \%$ (w/v) $\mathrm{HgCl}_{2}$ in the collection flask for each vessel immediately after emptying on the day before sampling.

Feed particle-associated (FPA) and feed particle-bound (FPB) fractions were prepared from the $48 \mathrm{~h}$ feed residues on days 22 and 25 , and from the $24 \mathrm{~h}$ residues on day 25 . Upon removal from the fermenter vessel and gentle squeezing to expel excess liquid, the alfalfa hay and barley grain feed bags were sealed together in a plastic bag with $20 \mathrm{ml}$ of McDougall (1948) buffer and processed for $60 \mathrm{~s}$ in a Stomacher 400 laboratory blender (Seward Medical Limited, London, UK). The processed liquid was squeezed out and retained, and the feed residues were washed twice with $10 \mathrm{ml}$ buffer. The two $10 \mathrm{ml}$ washings were combined with the initially expressed liquid, and the total volume was recorded. Subsamples of this fraction (FPA) were taken for determinations of xylanase activity and ${ }^{15} \mathrm{~N}$ in NAN. Washed feed residues (FPB fraction) were weighed for determination of $\mathrm{DM}$ and ${ }^{15} \mathrm{~N}$ enrichment. All samples were stored at $-40^{\circ} \mathrm{C}$ until analysed.

For ${ }^{15} \mathrm{~N}$ determinations, liquid samples were centrifuged (20 $000 \mathrm{~g} ; 30 \mathrm{~min} ; 4^{\circ} \mathrm{C}$ ), and the pellets were washed three times with $7 \mathrm{M}$-phosphate buffer $(\mathrm{pH} 7 \cdot 2)$, centrifuging $\left(20000 \mathrm{~g} ; 30 \mathrm{~min} ; 4^{\circ} \mathrm{C}\right)$ after each wash. The resulting pellet was resuspended in $5.0 \mathrm{ml}$ water, combined with $1.0 \mathrm{ml} 5 \%(\mathrm{w} / \mathrm{v}) \mathrm{NaOH}$ and dried at $75^{\circ} \mathrm{C}$. Feed residue samples were resuspended in $10 \mathrm{ml}$ buffer, and washed, dried and treated with base as for liquid samples. Dried materials were weighed and ground for measurement of total $\mathrm{N}$ and ${ }^{15} \mathrm{~N}$ enrichment by mass spectrometry using an NA 1500 nitrogen analyser (Carlo Erba Instruments, Rodano, MI, Italy).

Xylanase activity. On days 22 and 25, fermenter liquids from each vessel were sampled for determination of xylanase activity, as were the FPA fractions prepared for ${ }^{15} \mathrm{~N}$ determinations. Xylanase activity was measured as release 
of reducing sugars (RS) from oat spelt xylan during standardized incubation conditions, and was expressed as $\mu \mathrm{g}$ glucose equivalents released/min per $\mathrm{ml}$, for liquid fractions, or per g DM, for FPA fractions. Liquid and FPA samples were centrifuged $\left(20000 \mathrm{~g} ; 30 \mathrm{~min} ; 4^{\circ} \mathrm{C}\right)$ and xylanase activity was determined in the supernatant. Three millilitres of sample were combined with $3 \mathrm{ml}$ substrate solution $(2 \%$ suspension $(\mathrm{w} / \mathrm{v})$ oat spelts xylan in $0.2 \mathrm{M}-$ phosphate buffer, $\mathrm{pH} 6.0$ ), and incubated at $39^{\circ} \mathrm{C}$, with shaking, for $2 \mathrm{~h}$. Incubations were terminated by placing the tubes into boiling water for $10 \mathrm{~min}$. Incubation solutions were centrifuged $\left(20000 \mathrm{~g} ; 15 \mathrm{~min} ; 4^{\circ} \mathrm{C}\right)$ and the supernatants were assayed for RS (Nelson 1944) against a glucose standard.

Microbial enumeration. On day 13, homogenate was prepared from two fermenters in each treatment group by blending together fermenter liquid $(20 \mathrm{ml})$ and samples $(0.5 \mathrm{~g})$ from each of the $48 \mathrm{~h}$ feed bags (alfalfa hay and rolled barley grain) as described by Wang et al. (1998). Cellulolytic bacteria in the homogenates $(n$ 2) were enumerated by the most probable number method, and protozoa by light microscopy, also as described by Wang et al. (1998). The averages of values from the two fermenters are reported.

Feed and feed residues. Feed and feed residues were freeze-dried and ground (through a 1-mm screen), then analysed for DM $\left(105^{\circ} \mathrm{C}\right.$ for $3 \mathrm{~h}$ ) and organic matter (after ashing). Neutral-detergent fibre (NDF) was determined using the method of Van Soest et al. (1991). To solubilize starch and facilitate filtering during NDF analysis, heatstable $\alpha$-amylase (A-3306, Sigma Chemical Co.) was included at $0 \cdot 1 \%(\mathrm{v} / \mathrm{v})$ in the NDF solution added to feed samples $(50 \mathrm{ml} / 0.5 \mathrm{~g}$ sample). Total $\mathrm{N}$ was measured by MS (NA 1500, Carlo Erba Instruments). Reducing sugars in feeds were measured by mixing $5 \mathrm{~g}$ sample with $100 \mathrm{ml}$ boiling water, simmering for $5 \mathrm{~min}$, cooling in ice water, centrifuging (10 $000 \mathrm{~g} ; 10 \mathrm{~min})$ and analysing the supernatant for RS as described by Nelson (1944).

Calculations and statistics. Disappearances of DM from feed bags were determined gravimetrically and separately for rolled barley grain and alfalfa hay. Incorporation of ${ }^{15} \mathrm{~N}$ into microbial $\mathrm{N}$ in effluent, FPA and FPB fractions were calculated based on sample size (weight and volume), total NAN and ${ }^{15} \mathrm{~N}$ enrichments in the fractions produced daily. Total microbial ${ }^{15} \mathrm{~N}$ incorporation was the sum of incorporations in effluent and in $48 \mathrm{~h}$ feed bags. For measurements repeated on different days, data were combined across days for each fermenter vessel.

Data were analysed by one-way ANOVA, with treatment included as a main effect. Differences among treatments were tested using the least square means procedure of the SAS programming language, with the PDIFF (difference between $P$ values) option invoked (1991, Statistical Analysis Systems Institute Inc., Cary, NC, USA).

\section{Results}

Applying exogenous enzyme onto feed (EF) reduced $(P<$ $0.05) \mathrm{NDF}$ content and increased $(P<0.01) \mathrm{RS}$ content in barley grain but not in alfalfa hay (Table 1). Autoclaved
Table 1. Chemical composition (DM basis) of rolled barley grain and chopped alfalfa hay $24 \mathrm{~h}$ after treatment with water (control) or $1 \%$ solutions of a crude xylanase preparation (EF) or autoclaved enzyme (AEF)

\begin{tabular}{lcccc}
\hline & \multicolumn{3}{c}{ Treatment } & \\
\cline { 2 - 4 } & Control & EF & AEF & SEM \\
\hline Rolled barley & & & & \\
Organic matter (\%) & 97.28 & 97.26 & 97.10 & 0.939 \\
$\quad$ Neutral-detergent fibre (\%) & $29.13^{\mathrm{a}}$ & $26 \cdot 18^{\mathrm{b}}$ & $29.06^{\mathrm{a}}$ & 0.572 \\
Total N (\%) & 1.90 & 1.95 & 1.96 & 0.037 \\
$\quad$ Reducing sugars (mg/g DM) & $1.68^{\mathrm{d}}$ & $5.58^{\mathrm{c}}$ & $1.99^{\mathrm{d}}$ & 0.352 \\
Chopped alfalfa hay & & & & \\
$\quad$ Organic matter (\%) & 92.15 & 91.39 & 91.42 & 0.817 \\
$\quad$ Neutral-detergent fibre (\%) & 54.53 & 52.67 & 54.07 & 0.785 \\
$\quad$ Total N (\%) & 2.32 & 2.37 & 2.46 & 0.072 \\
Reducing sugars (mg/g DM) & 33.96 & 37.91 & 36.19 & 2.683 \\
\hline
\end{tabular}

a,b Within a row, values followed by different superscripts differ $(P<0.05)$.

c,d Within a row, values followed by different superscripts differ $(P<0.01)$.

enzyme did not affect the NDF or RS content of grain or hay $(P>0 \cdot 05)$. No differences in organic matter or total $\mathrm{N}$ contents were observed $(P>0.05)$ among $\mathrm{C}, \mathrm{EF}$ or AEF treatments for either feed type.

Disappearance of DM from barley grain was higher $(P<$ $0.05)$ with EF than with $\mathrm{C}, \mathrm{AEF}$ or EI, but treatment did not affect $(P>0.05)$ DMD from alfalfa hay or digestibility of NDF in either feed type (Table 2). Also unaffected $(P>$ $0.05)$ by treatment were volume of gas and proportion of methane produced from either substrate.

Cellulolytic bacteria were ten times more numerous in $\mathrm{EF}$ vessels than in $\mathrm{C}$, but protozoal numbers were similar among treatments (Table 3). Ammonia concentration in effluent from EF vessels was lower $(P<0.05)$ than from $\mathrm{C}$ or EI, but was similar $(P>0.05)$ to that in effluent from AEF vessels (Table 3). Total concentrations of VFA in vessel liquids were similar $(P>0.05)$ among treatments, but the molar proportion of propionate was higher $(P<$ $0 \cdot 05)$ with EF than with $\mathrm{C}$ or AEF. Treatment did not affect $(P>0.05)$ molar proportions of acetate and butyrate (Table 3) or other minor VFA (data not shown). Application of enzyme to the feed numerically increased the ${ }^{15} \mathrm{~N}$ enrichment in the microbial $\mathrm{N}$ (by $20 \%$ at $24 \mathrm{~h}$ and by $13 \%$ at $48 \mathrm{~h}$ ) of the FPA fraction, but not of the effluent, thus no significant effect of treatment on total ${ }^{15} \mathrm{~N}$ incorporation per $\mathrm{d}$ was observed. However, the amount of ${ }^{15} \mathrm{~N}$ incorporated in feed-related fractions $(\mathrm{FPA}+\mathrm{FPB})$ was higher $(P<0.05)$ with $\mathrm{EF}$ than with $\mathrm{C}$, AEF or EI.

Incorporation of ${ }^{15} \mathrm{~N}$ into the microbial protein associated with effluent, FPA and FPB fractions was affected by both exogenous fibrolytic enzyme and by application method (Table 4). Applying exogenous enzyme to feed before feeding $(\mathrm{EF})$ increased $(P<0.05)$ incorporation of ${ }^{15} \mathrm{~N}$ into FPB microbial $\mathrm{N}$ both at 24 and at $48 \mathrm{~h}$, relative to C. In contrast, AEF decreased $(P<0 \cdot 01){ }^{15} \mathrm{~N}$ incorporation into FPB microbial $\mathrm{N}$, but only at $24 \mathrm{~h}$. EI did not affect $(P>0.05){ }^{15} \mathrm{~N}$ incorporation into FPB microbial $\mathrm{N}$ at either time point.

Similar to the FPB, EF increased $(P<0.05)$, and AEF decreased $(P<0 \cdot 01){ }^{15} \mathrm{~N}$ incorporation into FPA microbial $\mathrm{N}$ at $24 \mathrm{~h}$, relative to $\mathrm{C}$ (Table 4). At $48 \mathrm{~h}$, however, 
Table 2. Effect of exogenous fibrolytic enzyme on DM disappearance (DMD), digestibility of neutral-detergent fibre (NDF), and gas production in the Rumen Simulation Technique†

\begin{tabular}{|c|c|c|c|c|c|}
\hline \multirow[b]{2}{*}{ Item } & \multicolumn{4}{|c|}{ Treatment $^{*}$} & \multirow[b]{2}{*}{ SEM } \\
\hline & $\mathrm{C}$ & EF & AEF & El & \\
\hline \multicolumn{6}{|l|}{ DMD at $48 \mathrm{~h}(\%)$} \\
\hline Rolled barley grain & $71.69^{b}$ & $75 \cdot 18^{\mathrm{a}}$ & $68 \cdot 97^{b}$ & $70 \cdot 23^{b}$ & 0.917 \\
\hline Chopped alfalfa hay & $50 \cdot 24$ & $51 \cdot 78$ & 49.58 & $50 \cdot 52$ & 0.976 \\
\hline \multicolumn{6}{|l|}{ NDF digestibility at $48 \mathrm{~h}(\%)$} \\
\hline Rolled barley grain & $50 \cdot 21$ & $47 \cdot 59$ & $46 \cdot 91$ & $48 \cdot 15$ & 1.502 \\
\hline Chopped alfalfa hay & 24.41 & 23.09 & 23.55 & $25 \cdot 71$ & 1.258 \\
\hline Gas production $(\mathrm{ml} / 24 \mathrm{~h}) \ddagger$ & 872 & 933 & 868 & 889 & $25 \cdot 5$ \\
\hline Proportion of methane in gas (\%) & 2.56 & 2.53 & 2.47 & $2 \cdot 24$ & 0.146 \\
\hline
\end{tabular}

C, control (no enzyme); EF, enzyme applied to feed; AEF, autoclaved enzyme applied to feed; El, enzyme infused with buffer.

$\mathrm{a}, \mathrm{b}$ Within a row, means bearing different superscripts differ $(P<0.05)$.

* Enzyme comprised xylanase concentrate applied at $1 \mathrm{mg} / \mathrm{g} \mathrm{DM}$.

† For details of procedures, see p. 326.

$\ddagger$ Average of volumes produced on days 16 to 21 inclusive.

incorporation was similar among treatments $(P>0.05)$. In effluent microbial $\mathrm{N}$, the amount of ${ }^{15} \mathrm{~N}$ incorporated was numerically higher $(603.9 \mu \mathrm{g}$ at $24 \mathrm{~h}$, averaged across treatments) than that incorporated into microbial $\mathrm{N}$ in FPB or FPA fractions (44.0 and $181.1 \mu \mathrm{g}$ respectively), but ${ }^{15} \mathrm{~N}$ incorporation in the effluent was unaffected $(P>0.05)$ by treatment.

Xylanase activity in the fermentation effluent was increased $(P<0.05)$ by enzymes, whether supplied on feed or in buffer (Table 5). Autoclaved enzyme did not affect xylanase activity. In all fermenter vessels, xylanase activity in the FPA fraction was higher at $48 \mathrm{~h}$ than at $24 \mathrm{~h}$ $(P<0.05)$, and at both time points it was higher $(P<$ 0.05) with EF than with AEF, EI or C. In the FPA fraction, the increase in xylanase activity between 24 and $48 \mathrm{~h}$ was numerically greater (104) in EF vessels than in C, AEF or EI (55, 69 and $50 \mu \mathrm{g}$ RS/g DM per min respectively).

\section{Discussion}

Applying a crude xylanase preparation to feed $24 \mathrm{~h}$ before fermentation increased microbial protein production in FPA and FPB fractions, increased ruminal cellulolytic bacterial numbers, increased xylanase activity in liquid and FPA fractions and increased DMD from rolled barley grain. Similar responses were not observed when enzyme was infused, suggesting that interaction between the enzyme and the feed before contact with ruminal fluid is required for enhancement of feed digestion.

Table 3. Effect of exogenous fibrolytic enzyme on protozoal and cellulolytic bacterial numbers, fermentative characteristics and incorporation of ${ }^{15} \mathrm{~N}$ into microbial $\mathrm{N}$ in the Rumen Simulation Technique $\dagger$

\begin{tabular}{|c|c|c|c|c|c|}
\hline \multirow[b]{2}{*}{ Item } & \multicolumn{4}{|c|}{ Treatment $^{*}$} & \multirow[b]{2}{*}{ SEM } \\
\hline & $\mathrm{C}$ & EF & AEF & $\mathrm{El}$ & \\
\hline Cellulolytic bacteria $\left(\times 10^{6} / \mathrm{ml}\right)$ & $0.49^{b}$ & $6 \cdot 70^{a}$ & $1 \cdot 32^{\mathrm{b}}$ & $2.52^{\mathrm{b}}$ & 0.903 \\
\hline Protozoa $\left(\times 10^{3} / \mathrm{ml}\right)$ & 2.78 & 2.56 & 2.78 & 2.44 & 0.223 \\
\hline Ammonia (mg N/l) & $126 \cdot 0^{a, b}$ & $116 \cdot 3^{\mathrm{c}}$ & $120 \cdot 9^{b, c}$ & $132 \cdot 2^{\mathrm{a}}$ & 2.64 \\
\hline Volatile fatty acids (mM) & 34.97 & $36 \cdot 20$ & $35 \cdot 32$ & 38.57 & 1.876 \\
\hline \multicolumn{6}{|l|}{ Molar proportions } \\
\hline Acetate & 0.53 & 0.56 & 0.53 & 0.57 & 0.0274 \\
\hline Propionate & $0.289^{\mathrm{b}, \mathrm{c}}$ & $0.339^{a}$ & $0.276^{c}$ & $0.334^{\mathrm{a}, \mathrm{b}}$ & 0.0166 \\
\hline Butyrate & 0.141 & 0.157 & 0.152 & 0.154 & 0.0216 \\
\hline \multicolumn{6}{|c|}{ Atom $\%$ excess of ${ }^{15} \mathrm{~N}$ in microbial $\mathrm{N}$} \\
\hline $\begin{array}{l}\text { Effluent } \\
\text { Feed particle-associated frac }\end{array}$ & $1 \cdot 793$ & $1 \cdot 794$ & $1 \cdot 846$ & $1 \cdot 815$ & $-\ddagger$ \\
\hline $24 \mathrm{~h}$ & 0.769 & 0.923 & 0.889 & 0.861 & $-\ddagger$ \\
\hline $48 \mathrm{~h}$ & 0.936 & 1.053 & 0.968 & 0.919 & $-\ddagger$ \\
\hline \multicolumn{6}{|l|}{ Microbial incorporation of ${ }^{15} \mathrm{~N}$} \\
\hline $\begin{array}{l}\text { Total }(\mu \mathrm{g} / 24 \mathrm{~h}) \| \\
\text { Feed related }(\mu \mathrm{g}) \|\end{array}$ & $638 \cdot 2$ & $667 \cdot 0$ & $676 \cdot 0$ & $621 \cdot 3$ & $25 \cdot 86$ \\
\hline $24 \mathrm{~h}$ & $212 \cdot 5^{\mathrm{b}}$ & $290 \cdot 4^{\mathrm{a}}$ & $158 \cdot 7^{\mathrm{b}}$ & $238 \cdot 9^{b}$ & 11.61 \\
\hline $48 \mathrm{~h}$ & $280 \cdot 7^{b}$ & $336 \cdot 9^{a}$ & $343 \cdot 1^{a}$ & $302 \cdot 4^{a, b}$ & $15 \cdot 56$ \\
\hline
\end{tabular}


Table 4. Incorporation of ${ }^{15} \mathrm{~N}$ into microbial $\mathrm{N}(\mu \mathrm{g})$ in effluent and in the feed particle-associated and feed particle-bound fractions during 24 and $48 \mathrm{~h}$ incubations of alfalfa hay or rolled barley grain in the Rumen Simulation Technique†

\begin{tabular}{|c|c|c|c|c|c|}
\hline \multirow[b]{2}{*}{ Sample type } & \multicolumn{4}{|c|}{ Treatment $^{*}$} & \multirow[b]{2}{*}{ SEM } \\
\hline & $\mathrm{C}$ & EF & $\mathrm{AEF}$ & $\mathrm{El}$ & \\
\hline Effluent (24 h) & $605 \cdot 7$ & $619 \cdot 6$ & $640 \cdot 2$ & $550 \cdot 2$ & $27 \cdot 71$ \\
\hline \multicolumn{6}{|c|}{ Feed particle-associated fraction } \\
\hline $24 \mathrm{~h}$ & $169 \cdot 6^{\mathrm{b}}$ & $236 \cdot 7^{\mathrm{a}}$ & $128 \cdot 5^{\mathrm{c}}$ & $189 \cdot 7^{b}$ & 14.83 \\
\hline $48 \mathrm{~h}$ & $232 \cdot 7$ & $280 \cdot 4$ & $289 \cdot 7$ & $267 \cdot 5$ & $22 \cdot 34$ \\
\hline \multicolumn{6}{|c|}{ Feed particle-bound fraction } \\
\hline $24 \mathrm{~h}$ & $42 \cdot 9^{b}$ & $53 \cdot 7^{\mathrm{a}}$ & $30 \cdot 2^{c}$ & $49 \cdot 2^{a, b}$ & 2.55 \\
\hline $48 \mathrm{~h}$ & $48 \cdot 2^{\mathrm{b}}$ & $56 \cdot 5^{a}$ & $53 \cdot 4^{\mathrm{a}, \mathrm{b}}$ & $54 \cdot 9^{a, b}$ & 1.58 \\
\hline
\end{tabular}

C, control (no enzyme); EF, enzyme applied to feed; AEF, autoclaved enzyme applied to feed; El, enzyme infused with buffer.

a,b,c Within a row, means bearing different superscripts differ $(P<0.05)$.

* Enzyme comprised xylanase concentrate applied at $1 \mathrm{mg} / \mathrm{g} \mathrm{DM}$.

† For details of procedures, see p. 326.

Responses to enzyme applied to the feed were related to both pre-incubation and post-incubation effects (Table 1). Other studies have also indicated that spraying aqueous enzyme onto feed before consumption (to moisture levels equalling $10 \%$ of the total DM) enables release of RS from substrate by the fibrolytic enzyme(s) before contact with rumen microbial populations (Beauchemin \& Rode, 1996; Hristov et al. 1996). Supplying enzyme in the buffer afforded no pre-feeding opportunity for enzymic hydrolysis of substrate. Metabolic products of primary colonizers of feedstuffs are thought to attract secondary colonizers to feed surfaces and stimulate attachment (Cheng \& McAllister, 1997). Thus, the released products of hydrolysis that accumulated on the surface of the feed particles may have elicited a similar chemotactic response that enhanced attachment of ruminal microbes to feed particles. Ruminal micro-organisms typically must circumvent physical barriers to colonization (e.g. cuticle, pericarp) and access internal, readily digestible tissues via stomata, lenticels or damaged areas (Cheng et al. 1983/84). By cleaving specific bonds in structural polymers, applied enzymes may weaken the surface of feed particles, thereby removing some of these physical barriers that impede microbial attachment. This possibility is supported by the observations that

Table 5. Effect of exogenous fibrolytic enzyme on xylanase activity in fermenter effluent and in feed particle-associated (FPA) fractions in the Rumen Simulation Technique†

\begin{tabular}{|c|c|c|c|c|c|}
\hline \multirow[b]{2}{*}{ Item } & \multicolumn{4}{|c|}{ Treatment* } & \multirow[b]{2}{*}{ SEM } \\
\hline & C & EF & AEF & El & \\
\hline \multicolumn{6}{|c|}{ Xylanase activity $\ddagger$} \\
\hline $\begin{array}{l}\text { Effluen } \\
\text { FPA fra }\end{array}$ & $0.95^{b}$ & $1.91^{\mathrm{a}}$ & $0.79^{b}$ & $1.91^{\mathrm{a}}$ & 0.159 \\
\hline $24 \mathrm{~h}$ & $79 \cdot 7^{\mathrm{b}}$ & $133 \cdot 3^{\mathrm{a}}$ & $73 \cdot 9^{b}$ & $73 \cdot 1^{\mathrm{b}}$ & $7 \cdot 25$ \\
\hline $48 \mathrm{~h}$ & $134 \cdot 2^{b}$ & $237.5^{\mathrm{a}}$ & $144 \cdot 1^{b}$ & $123 \cdot 1^{\mathrm{b}}$ & $7 \cdot 60$ \\
\hline
\end{tabular}

$C$, control (no enzyme); EF, enzyme applied to feed; AEF, autoclaved enzyme applied to feed; El, enzyme infused with buffer.

a,b Within a row, means bearing different superscripts differ $(P<0.05)$.

* Enzyme comprised xylanase concentrate applied at $1 \mathrm{mg} / \mathrm{g} \mathrm{DM}$.

†For details of procedures, see p. 326.

fExpressed as release of reducing sugars (RS). In effluent, activity is expressed as $\mu \mathrm{g} \mathrm{RS} / \mathrm{ml}$ per min. On feed particles, activity is expressed as $\mu \mathrm{g} \mathrm{RS} / \mathrm{g}$ DM per min. exogenous enzymes tend to lower the NDF and aciddetergent fibre contents of feeds (Gwayumba \& Christensen, 1996; Hristov et al. 1996), and also by the decrease in NDF content of barley grain observed in the present study, but not by the observation that NDF content of alfalfa hay remained unchanged.

The observation that, in effluent, xylanase activity was higher with either EF or EI than with $\mathrm{C}$, but that, in FPA fractions, it was higher only with $\mathrm{EF}$ relative to $\mathrm{C}$ (Table 5) may have resulted both from the attachment of exogenous enzyme to the feed particles, and from endogenous production of xylanases by bacteria attached to the feed. It is possible that binding to feed particles increases the resistance of exogenous enzyme to ruminal proteolysis, as compared to enzyme introduced into effluent. These factors suggest that applying exogenous enzymes to feed prior to consumption may be advantageous compared to feeding them directly.

This present study indicated that the efficacy of exogenous enzymes is affected not only by the method of application, but also by the type of feed to which they are applied. Applied to feeds prior to feeding, enzymes significantly increased $48 \mathrm{~h}$ DMD from barley grain, but not from alfalfa hay (Table 2). This distinction between feed types probably arises from both pre- and postincubation responses to the exogenous enzyme. Enzymes applied to feed increased RS and decreased NDF content in barley grain but not alfalfa hay (Table 1). Diet-specific effects have been observed with other enzyme preparations (Hristov et al. 1996; Beauchemin et al. 1997), and we have also observed a similar phenomenon with pure cultures of bacteria, conceivably due to the profile of bacterial enzymes produced.

The extent to which complex feed substrates are degraded by pure cultures of bacteria is dependent upon the bacterial species (Dehority \& Scott, 1967; Kudo et al. 1987). In our laboratory, Fibrobacter succinogenes more readily digested barley straw than alfalfa hay, whereas Ruminococcus flavefaciens was more effective at degrading alfalfa hay than barley straw (Y Wang, D Morgavi and T McAllister, unpublished results), and in a related experiment, the enzyme preparation used in the present study was stimulatory to $F$. succinogenes but not to $R$. flavefaciens. In agreement with that pure culture work, scanning electron microscopy of $12 \mathrm{~h}$ feed residues collected during the present Rusitec study confirmed that the predominant colonizing bacteria comprised different morphotypes on barley grain than on alfalfa hay, and that the morphological diversity among bacteria colonizing alfalfa hay was enhanced on EF, compared to C, AEF and EI (data not shown). It is possible, therefore, that the pre-feeding effects of exogenous enzyme may influence the digestive rumen microbiota, and thereby contribute to the differing effects of enzyme treatment between diets.

The hydrolytic release of RS from feed at $90 \%$ DM occurred immediately following the application of enzyme solutions that increased moisture content by a further $10 \%$ DM. Evaporation of this moisture, or its penetration into the feed particle, may limit the duration of this pre-ruminal hydrolysis. Some studies have shown that most of the RS release from high DM feeds affected by exogenous 
enzymes occurs within $2 \mathrm{~h}$ of application (Nsereko et al. 2000). This pre-ruminal hydrolysis, albeit short-term, may play a critical role in the subsequent microbial colonization in mixed cultures. Although EF treatment decreased dietary NDF content in this present study, the extent of NDF digestion by ruminal microbes was not affected. This increase in initial solubilization of NDF independent of overall true digestibility was also reported by Chademana \& Offer (1990), Erasmus et al. (1992) and Kumar et al. (1994), when Saccharomyces cerevisiae was used as a feed additive. A number of studies with various enzyme products showed that most of the preparations did not affect the extent of the digestion (Chen et al. 1995; Feng et al. 1996; Hristov et al. 1996, 1998; McAllister et al. 2000), although some showed that the rate of digestion was improved to a certain degree (Yang et al. 1999). Increasing the extent of digestion of feeds may be key to improving the efficacy of an enzyme for ruminant diets.

Increased incorporation of ${ }^{15} \mathrm{~N}$ into both FPA and FPB microbial $\mathrm{N}$ with $\mathrm{EF}$ indicates that this treatment increased microbial attachment and increased colony growth following attachment, as was indicated by electron microscopy. Microbial attachment to substrate is thought to be the main factor in determining digestibility of fibre; it has been shown that over $85 \%$ of cellulase, hemicellulase and glycosidase activities are associated with feed particles in the rumen (Williams \& Strachan, 1984). Similar proportions of micro-organisms have been shown to be associated with solid digesta in vivo (Craig et al. 1987; Legay-Carmier \& Bauchart, 1989) and in the Rusitec (Cheng \& McAllister, 1997). Higher cellulolytic bacterial numbers and xylanase activity in the FPA fraction in the present study indicate that the increased attachment probably comprises mainly cellulolytic species. The increase in xylanase activity between 24 and $48 \mathrm{~h}$, which was due to microbial activity, was notably larger with EF than it was with other treatments (104 v. $58 \mu \mathrm{g}$ RS released/g DM per min, on average). Enhanced cellulolytic activity with enzyme treatment was also observed in in vitro studies with Aspergillus niger (Leatherwood et al. 1960) and with a whole cell product based on A. oryzae (Newbold et al. 1991, 1996), as well as with a number of exogenous fibrolytic preparations in vivo (Yang et al. 1999). These findings may also reflect a shift in the species profile of colonizing bacteria in response to pre-feeding treatment of the feeds with enzyme.

Increased cellulolytic bacterial numbers typically occur concurrently with generally increased bacterial numbers (Dawson 1987; Wiedmeier et al. 1987; Harrison et al. 1988; Frumholtz et al. 1989; Newbold et al. 1996). However, in the present study, similar $24 \mathrm{~h}$ levels of ${ }^{15} \mathrm{~N}$ incorporation into microbial $\mathrm{N}$ across treatments indicated that total microbial mass was not changed. This observation, together with increased cellulolytic activity and reduced ammonia concentration in fermenter vessel liquid (Table 2), suggests that certain microbial populations, rather than total biomass, were affected by EF treatment.

Reduced ${ }^{15} \mathrm{~N}$ incorporation into FPA fractions at $24 \mathrm{~h}$ with AEF (Table 4) is difficult to explain, but may be related to non-enzymic components in the crude fungal extract. Some fungal extracts contain metabolic intermediates that stimulate ruminal bacteria (Nisbet \& Martin, 1989), but some also contain preservatives that inhibit microbial activity (Alexander, 1971; Stewart et al. 1992; Odenyo et al. 1994). It is possible that some of these inhibitory substances impeded initial colonization of the substrate. This may have been reflected in the observation of decreased ${ }^{15} \mathrm{~N}$ incorporation into microbial $\mathrm{N}$ at $24 \mathrm{~h}$ in the feed-related (FPB and FPA) fractions treated with AEF. Similar levels of incorporation between AEF and $\mathrm{C}$ at $48 \mathrm{~h}$ suggest that the inhibition was temporary, but the presence of these inhibitory substances may have prevented realization of the full benefits of supplemental enzymes.

\section{Acknowledgements}

Funding for this project was provided in part by Monsanto and by the Matching Investment Initiative of Agriculture and Agri-Food Canada. The authors thank L. R. McMahon, R. Klvacek and $\mathrm{Z}$. Xu for technical assistance, and K. Jakober for assistance with manuscript preparation. This is LRC contribution number 3879912.

\section{References}

Alexander M (1971) Microbial Ecology, New York: John Wiley \& Sons.

Beauchemin KA \& Rode LM (1996) Use of feed enzymes in ruminant nutrition. In Animal Science Research and Development - Meeting Future Challenges, pp. 103-131 [LM Rode, editor]. Ottawa, Ont., Canada: Minister of Supply and Services Canada.

Beauchemin KA, Rode LM \& Sewalt VJH (1995) Fibrolytic enzymes increase fibre digestibility and growth rate of steers fed dry forages. Canadian Journal of Animal Science 75, 641644.

Beauchemin KA, Jones SDM, Rode LM \& Sewalt VJH (1997) Effects of fibrolytic enzymes in corn or barley diets on performance and carcass characteristics of feedlot cattle. Canadian Journal of Animal Science 77, 645-653.

Beauchemin KA, Rode LM, Yang WZ \& McAllister TA (1998) Use of feed enzyme in ruminant nutrition. In Proceedings of 33rd Annual Pacific Northwest Animal Nutrition Conference and Chr. Hansen Biosystems Pre-conference Symposium, pp. 121-135. Vancouver, BC, Canada.

Chademana I \& Offer NW (1990) The effect of dietary inclusion of yeast culture on digestion in the sheep. Animal Production 50, 483-489.

Chen KH, Huber JT, Simas J, Theurer CB, Yu P, Chan SC, Santos F, Wu Z, Swingle RS \& DePeters EJ (1995) Effect of enzyme treatment or steam-flaking of sorghum grain on lactation and digestion in dairy cows. Journal of Dairy Science 78, 1721-1727.

Cheng K-J \& McAllister TA (1997) Compartmentation in the rumen. In The Rumen Microbial Ecosystem, 2nd ed, pp. 492522 [PN Hobson and CS Stewart, editors]. London: Blackie Academic \& Professional.

Cheng KJ, Stewart CS, Dinsdale D \& Costerton JW (1983/84) Electron microscopy of bacteria involved in the digestion of plant cell walls. Animal Feed Science and Technology 10, 93120.

Craig WM, Broderick GA \& Ricker DB (1987) Quantitation of microorganisms associated with particular phase of rumen ingesta. Journal of Nutrition 117, 56-62. 
Czerkawski JW \& Breckenridge G (1977) Design and development of a long-term rumen simulation technique (rusitec). British Journal of Nutrition 38, 371-374.

Dawson KA (1987) Mode of action of the yeast culture, Yea-Sacc, in the rumen: a natural fermentation modifier. In Biotechnology in the Feed Industry. Proceedings of Alltech's 2nd Annual Symposium, pp. 119-126 [TP Lyons, editor]. Nicholasville, Kentucky, USA: Alltech Technical Publications.

Dehority BA \& Scott HW (1967) Extent of cellulose and hemicellulose digestion in various forages by pure cultures of rumen bacteria. Journal of Dairy Science 50, 1136-1141.

Erasmus LJ, Botha PM \& Kistner A (1992) Effect of yeast culture supplementation on production, rumen fermentation, and duodenal nitrogen flow in dairy cows. Journal of Dairy Science 44, 1899-1902.

Feng P, Hunt CW, Pritchard GT \& Julien WE (1996) Effect of enzyme preparations on in situ and in vitro degradation and in vivo digestive characteristics of mature cool-season grass forage in beef steers. Journal of Animal Science 74, 1349-1357.

Flint HJ \& Forsberg CW (1995) Polysaccharide degradation in the rumen: biochemistry and genetics. In Rumen Physiology: Digestion, Metabolism, Growth and Reproduction, pp. 43-70 [Wv Engelhardt, S Leonhard-Marek, G Breves and D Giesecke, editors]. Stuttgart, Germany: Ferdinand Enke Verlag.

Frumholtz PP, Newbold CJ \& Wallace RJ (1989) Influence of Aspergillus oryzae fermentation extract on the fermentation of basal ration in the rumen simulation technique (Rusitec). Journal of Agricultural Science (Cambridge) 113, 169-172.

Gwayumba W \& Christensen DA (1996) The effect of fibrolytic enzymes on protein and carbohydrate degradation fractions in forages. In Proceedings of 46th Annual Meeting, Canadian Society of Animal Science, p. 2. Lethbridge, Alberta, Canada: Canadian Society of Animal Science.

Harrison GA, Hemben RW, Dawson KA, Harmon RJ \& Barker KB (1988) Influence of addition of yeast culture supplement to diets of lactating cows on ruminal fermentation and microbial populations. Journal of Dairy Science 71, 29672975.

Hristov AN, Rode LM, Beauchemin KA \& Wuerfel RL (1996) Effect of a commercial enzyme preparation on barley silage in vitro and in sacco dry matter degradability. Proceedings of the Western Section, American Society of Animal Science 47, 282284.

Hristov AN, McAllister TA \& Cheng K-J (1998) Effect of dietary or abomasal supplementation of exogenous polysaccharidedegrading enzymes on rumen fermentation and nutrient digestibility. Journal of Animal Science 76, 3146-3156.

Kudo H, Cheng KJ \& Costerton JW (1987) Interactions between Treponema bryantii and cellulolytic bacteria in the in vitro degradation of straw cellulose. Canadian Journal of Microbiology 33, 244-248.

Kumar U, Sareen VK \& Singh S (1994) Effect of Saccharomyces cerevisiae yeast culture supplement on rumen metabolism in buffalo calves given a high concentrate diet. Animal Production 59, 209-215.

Leatherwood JM, Morechrie RD \& Thomas WE (1960) Some effects of a supplementary cellulase preparation on feed utilization by ruminants. Journal of Dairy Science 43, 14601464.

Legay-Carmier F \& Bauchart D (1989) Distribution of bacteria in the rumen contents of dairy cows given a diet supplemented with soya-bean oil. British Journal of Nutrition 61, 725-740.

Lewis GE, Sanchez WK, Treacher R, Hunt CW \& Pritchard GT (1995) Effect of direct-fed fibrolytic enzymes on lactational performance of midlactation Holstein cows. Proceedings of the
Western Section, American Society of Animal Science and the Canadian Society of Animal Science 46, 310-313.

McAllister TA, Bae HD, Jones GA \& Cheng K-J (1994) Microbial attachment and feed digestion in the rumen. Journal of Animal Science 72, 3004-3018.

McAllister TA, Oosting SJ, Popp JD, Mir Z, Yanke LJ, Hristov AN, Treacher RJ \& Cheng K-J (1999) Effect of exogenous enzymes on the digestibility of barley silage and growth performance of feedlot cattle. Canadian Journal of Animal Science 79, 353-360.

McAllister TA, Stanford K, Bae HD, Treacher RJ, Baah J, Shelford JA \& Cheng K-J (2000) Effect of a surfactant and exogenous enzymes on digestibility, growth performance and carcass traits of lambs. Canadian Journal of Animal Science $\mathbf{8 0}$, $35-44$.

McDougall EI (1948) Studies on ruminant saliva 1. The composition and output of sheep's saliva. Biochemical Journal 43, 99-109.

Nelson N (1944) A photometric adaptation of the Somogyi method for the determination of glucose. Journal of Biological Chemistry 153, 375-380.

Newbold CJ, Brock R \& Wallace RJ (1991) Influence of autoclaved or irradiated Aspergillus oryzae fermentation extract on fermentation in the rumen simulation technique (Rusitec). Journal of Agricultural Science (Cambridge) 116, $159-162$.

Newbold CJ, Wallace RJ \& McIntosh FM (1996) Mode of action of the yeast Saccharomyces cerevisiae as a feed additive for ruminants. British Journal of Nutrition 76, 249-261.

Nisbet DJ \& Martin SA (1989) Factors affecting lactate uptake by Selenomonas ruminantium HD4. Proceedings of the 20th Biennial Conference on Rumen Function p. 8. Chicago, IL, USA.

Nsereko VL, Morgavi DP, Rode LM, Beauchemin KA \& McAllister TA (2000) Effects of fungal enzyme preparations on hydrolysis and subsequent degradation of alfalfa hay fibre by mixed rumen microorganisms in vitro. Animal Feed Science and Technology (In the Press).

Odenyo AA, Mackie RI, Stahl DA \& White BA (1994) The use of $16 \mathrm{~S}$ rRNA probes to study competition between rumen fibrolytic bacteria: development of probes for Ruminococcus species and evidence for bacteriocin production. Applied and Environmental Microbiology 60, 3688-3696.

Stewart CS, Duncan SH \& Richardson AJ (1992) The inhibition of fungal cellulolysis by cell-free preparations from ruminococci. FEMS Microbiological Letters 72, 47-50.

Stokes MR \& Zhang S (1995) The use of carbohydrase enzymes as feed additives for early lactation cows. Proceedings of the 23rd Biennial Conference on Rumen Function p. 35. Chicago, IL, USA.

Svozil B, Votava J, Zobac P \& Horvak V (1989) Application of the cellulolytic preparation in nutrition of lambs. Sbornik Vědeckych Praci Vyzkummy Ústav Vyzivy Zvirat Pohořelice 22, 69-78.

Theurer B, Woods W \& Burroughs W (1963) Influence of enzyme supplements in lamb fattening rations. Journal of Animal Science 22, 150-154.

Treacher R, McAllister TA, Popp JD, Mir Z, Mir P \& Cheng K-J (1996) Effects of exogenous cellulases and xylanases on feed utilization and growth performance of feedlot steers. Canadian Journal of Animal Science 77, 541 (Abstract).

Van Soest PJ, Robertson JB \& Lewis BA (1991) Methods for dietary fibre, neutral detergent fibre, and non-starch polysaccharides in relation to animal nutrition. Journal of Dairy Science 74, 3583-3597.

Wang Y, McAllister TA, Newbold CJ, Cheeke PR \& Cheng K-J (1998) Effect of Yucca schidigera extract on fermentation and 
degradation of steroidal saponins in the rumen simulation technique (RUSITEC). Animal Feed Science and Technology 74, 143-153.

Wiedmeier RD, Arambel MJ \& Walters JL (1987) Effect of yeast culture and Aspergillus oryzae fermentation extract on ruminal characteristic and nutrient digestion. Journal of Dairy Science 70, 2063-2068.
Williams AG \& Strachan NH (1984) The distribution of polysaccharide-degrading enzymes in the bovine rumen digesta ecosystem. Current Microbiology 10, 215-220.

Yang WZ, Beauchemin KA \& Rode LM (1999) Effects of enzymes feed additives on extent of digestion and milk production of lactating dairy cows. Journal of Dairy Science 82, 391-403. 